\title{
The effect of alliance experience and intellectual capital on the value creation of international strategic alliances
}

\author{
Shao-Chi Chang ${ }^{\mathrm{a}, *}$, Sheng-Syan Chen ${ }^{\mathrm{b}}$, Jung-Ho Lai ${ }^{\mathrm{c}}$ \\ ${ }^{a}$ Institute of International Business, National Cheng Kung University, Taiwan \\ ${ }^{\mathrm{b}}$ Department of Finance, National Taiwan University, Taiwan \\ ${ }^{\mathrm{c}}$ Department of International Business, Southern Taiwan, University of Technology, Taiwan \\ Received 9 January 2005; accepted 21 June 2006 \\ Available online 26 September 2006
}

\begin{abstract}
This paper investigates the effects of intellectual capital (IC), alliance experience and their interaction on the value creation of international strategic alliances (ISAs). Based on a sample of ISAs formed by US firms, we find that firms with a higher level of IC receive greater announcement-period wealth gains. In addition, the empirical results suggest experience positively enhances the wealth effect of ISAs. Finally, we find a significant positive interaction effect between experience and IC on the wealth creation of ISAs. The results demonstrate the importance of considering the joint effects of IC and experience in assessing the value creation of ISAs.
\end{abstract}

(C) 2006 Elsevier Ltd. All rights reserved.

Keywords: Learning effect; Intellectual capital; Tobin's q; Experience content; Strategic alliances; Wealth effect

\section{Introduction}

Research in organizational behavior [1,2], marketing $[3,4]$, and international business $[5,6]$ has advanced the state of knowledge by highlighting various advantages of inter-firm collaboration. International strategic alliances (ISAs) enhance firm value by allowing partnering firms to keep abreast of rapidly changing technologies [7], spread the costs and risks of innovation [8], gain access to specific foreign markets and distribution channels [9], and learn the country-specific comparative advantages embedded in their partners (e.g., see $[9,10])$ etc.

\footnotetext{
* Corresponding author. Tel.: +88662757575; fax: +88662746459 .

E-mail address: schang@mail.ncku.edu.tw (S.-C. Chang).
}

Yet, there is also a widespread recognition of the difficulties inherent in the cooperation process (see, for example, [11-13] etc.). Studies indicate that roughly half of all alliances formed end up failing [11,14]. Taken together, the coexistence of value creation and the inherent instability of alliances lead to the intriguing question of what firms can do to enhance the possibility of success and maximize wealth gains from alliance activities.

Prior studies have argued that one of the most important determinants of alliance success is prior cooperative experience $[15,16]$. In essence, alliances are incomplete contracts because ex ante it is often impossible to completely specify contingencies that may arise in the implementation of the agreements [17]. The self-governance feature [18] and self-interest orientation [19] further complicate fragile cooperative relationships. In such a situation, experience may play 
an important role in the stability of inter-firm collaboration. As firms accumulate experiences, their increasing abilities to anticipate and respond to those contingencies are likely to enhance the chances of success in subsequent alliances [16].

While greater experience may be a necessary condition for firms to build alliance capability, it may not be sufficient to achieve the maximum benefits from alliance activities. Firms differ in their abilities to appropriate knowledge from alliances [20]. Anand and Khanna [16] found a strong and persistent heterogeneity in the alliance capabilities of firms. Anecdotal evidence and case-based research also suggest that some firms do develop superior abilities to manage alliances and appropriate partner knowledge through repeated experiences $[14,21]$. Accordingly, while prior experience is important, it may at best be a crude proxy for the precise mechanisms that build alliance capability. Further alliance capability enhancement may rest upon how effectively a firm is able to capture, share, and disseminate the learnt know-how associated with prior experiences [22,23].

Given its importance, however, the question of what differentiates firms' learning capabilities remains under-researched [23]. Augmented by the concepts of knowledge management and organizational learning, this study seeks to construct a comprehensive framework of value creation in the inter-firm experiential learning process. In this research, the role of a firm's intellectual capital (IC) is specifically examined. We address the issue of how a firm's IC, previous alliance experience, and their interaction affect value creation in ISA activities.

IC represents knowledge-related intangible assets embedded in an organization. The literature suggests that IC is composed of the following three dimensions: structural capital, relational capital, and human capital [24-30]. Its importance is underlined in the era of a knowledge-based economy, where IC, instead of traditional tangible assets, is the dominant value driver for an enterprise $[1,24,31]$. The literature has shown that IC plays an important role in corporate performance, particularly for firms in unstable and variant environments, such as the information technology industry [32], biotechnology industry [30], emerging economies $[32,33]$, and high-technology new ventures [33].

With this in mind, we argue that the embedded instability and uncertainty associated with alliances make strong demands on IC. The contractual incompleteness in alliances tends to result in opportunistic exploitation among partnering firms that in turn may lead to severing of the agreements [34]. Because IC represents an organizationally embedded competency that is valuable in managing uncertain situations, we argue that IC should have a positive influence on the management of alliances. Firms with better IC should realize greater gains from inter-firm collaboration.

Generally, firms confronted with changing knowledge environments should, to a large extent, aim at reconfiguring their existing knowledge or developing new knowledge. With this in mind, this study further highlights the interaction effect of IC with prior alliance experience. We argue that this interaction should amplify a given firm's knowledge base through which a firm's alliance capability can be incrementally developed. Kale et al. [23] argued that lessons learnt from experiences are of little use without proper storage and integration. IC helps firms in the experiential learning process by effective transformation of these learnt lessons into concrete alliance capabilities. The contexts of IC are further refined and adjusted based on the signals from the environment and stimuli from each previous alliance experience. The iterative, mutually reinforcing process between IC and alliance experience thus has an important beneficial impact on value creation from ISA activities.

In this study, we explore the effects of IC, experience and their interaction on wealth creation using a sample of non-equity involved ISAs. Previous studies on the issue of inter-firm experiential learning have focused largely on joint ventures, and results are mixed. ${ }^{1}$ Instead of joint ventures, we have chosen nonequity, contractual ISAs as the sample since without equity investment, contractual alliances are likely to involve greater risks and uncertainty than joint ventures. Equity investment in joint ventures functions to align mutual interests among partners [38]. It also provides hierarchical controls which simplify the decision making process and make the alliance process more predictable [39]. In contrast, without equity participation, contractual alliances have to rely more on cooperative know-how to cope with collaboration difficulties. Since IC and experience are expected to be more important when the transactions involve greater risks and uncertainty, we believe the influence of IC and experience will be stronger in non-equity alliances than in joint ventures. For similar reasons, we selected international alliances rather than domestic alliances as the sample to test our hypotheses. Cross-border cooperations are far more complex than domestic ones because of the greater diversity and variation in

\footnotetext{
${ }^{1}$ Please see Barkema and Vermeulen [35], Anand and Khanna [16], Gupta and Misra [36] and Merchant and Schendel [37].
} 
partner characteristics [40]. The higher degree of information asymmetry among partners in international alliances may further lead to serious problems of opportunistic behaviors. Consequently, the success of ISAs will rely more on a firm's ability to manage crossborder collaboration based on its prior experiences and IC.

The issue we address here is important in the following respects. First, though it is widely recognized that different rates of learning exist among firms, the factors underlying these differences in firm learning efficiency have not been clearly elucidated in the literature. Exploring the role of IC both clarifies the experiential learning process, and illuminates the causes of the different learning rates among ISA partnering firms. Next, despite the increasing importance of IC, little research has focused on the relationship between IC assets and firm value creation. Most research on IC has primarily been aimed at its definition, classification and measurement [41]. To the best of our knowledge, the impact of IC on the value creation of inter-firm cooperation has never been explored before in the literature. This study directly investigates this question. Finally, literature on the wealth effects of experience on non-equity alliances is lacking. Given the mixed evidence of the effect of experience on joint ventures, this research may shed new light on the issues.

The remainder of the paper is organized as follows. The next section reviews the literature on IC and the learning effect in ISAs and proposes a number of testable hypotheses. The third section outlines the sample selection and methodology. The fourth section presents the empirical findings. The final section discusses the findings, draws some implications, and concludes.

\section{Theory and hypotheses}

In this section, we integrate views from resource and knowledge-based perspectives, dynamic capability, evolutionary economics and organizational learning, to propose that a firm's IC, prior experience, and their interaction have important impacts on alliance capability, which in turn influences the value creation of ISAs.

\subsection{The value of IC in ISAs}

The resource-based view of the firm states that firms are heterogeneous because they are essentially a collection of sticky and difficult-to-imitate resources [42]. Expanding on this argument, the knowledge-based perspective further focuses on knowledge as the most strategically significant resource of a firm [43]. This argument is supported by the increasingly important concept of IC, which is recognized as an important value driver of the enterprise. In the discussion below, the idea of IC is first elaborated, and then its contribution to value creation in ISAs is clarified.

\subsubsection{Intellectual capital}

IC represents knowledge-related intangible assets embedded in an organization. The IC literature generally agrees that IC is composed of three elements: structural capital, human capital, and relational capital [24-30]. Structural capital refers to the non-human storehouses of knowledge in a firm that involve organizational structures, such as the organizational routines, the structure of the business, and various types of intellectual property. Human capital denotes the tacit knowledge embedded in the minds of the employees. Roos et al. [44] argued that employees generate IC through their competence, attitude, motivation, and intellectual agility. Relational capital represents the knowledge embedded in the relationships with the outside environment. It's the potential an organization has due to ex-firm intangibles. Many researchers contend that IC greatly assists enterprises in promoting competitive advantages (e.g., $[29,30])$. We argue that IC is particularly important in ISAs because of the high degree of uncertainty and complexity involved in inter-firm collaborations.

\subsubsection{Leveraging IC to create value through alliances}

Inter-firm knowledge flow is usually more difficult than intra-firm knowledge flow because of the lack of a shared understanding, and differences in standards and social origins [45]. IC may facilitate interfirm knowledge exchange in several ways. For firms with greater IC, for instance, quality personnel may serve to span the boundaries between a firm and its external network. They are capable of overcoming the knowledge flow barriers through properly conveying and transforming external information into knowledge understandable to other members of the firm they represent. This capability is particularly significant when the expertise of most individuals within the organization differs considerably from that of the external actors providing information [46,47]. Further, while quality personnel provide a platform for transferring external knowledge for internal utilization, organizational structures are also essential to ensure successful inter-firm organizational learning. With the aid of well designed, learning-oriented organizational structures, the learnt knowledge is properly accumulated, stored, 
integrated, and diffused across the organizational subunits [23]. Therefore, IC makes important contributions to a firm's learning in alliances by facilitating transmission of information inward, and by ease of assimilation, transformation, and exploitation of learnt know-how from ISA activities. This enhanced learning capability is thought to benefit firm performance $[48,49]$. According to the resource-based view of the firm, the embeddedness of valuable, firm-specific knowledge forms the source of a firm's sustainable competitive advantage [50]. Since an alliance functions as a platform to access a partner's tacit, embedded know-how [51], firms with stronger learning capability are thought to be more capable of using this platform to gain tacit benefits, sustain competitiveness, and excel in market and financial performance.

In addition to the enhancement of learning capability, IC aids firms in the cooperation process. Cross-border cooperation is fraught with risks. ISAs can fail for any number of reasons: lack of strategic fit in complementary resources [11], lack of organizational fit in cultures, decision-making processes, and systems [13], lack of trust [12], inability to manage conflict [52], and many others. Facilitated by well-constructed organizational structures, firms systematize the routine implementation of alliance affairs, creating guidelines to handle specific aspects of the alliance life cycle (e.g., partner selection, alliance negotiation, contract formulation, and finally relationship termination). In this regard, IC fosters the development of cooperative skills.

Finally, IC aids alliance participants in accessing complementary resources through efficient utilization of the relational assets. Structural sociologists suggest that the most important facet of an organization's environment is its social network of external contacts [53], since efficient information access provides a basis for action but is costly to gather [54]. This information concern is especially urgent for firms operating in conditions of great uncertainty, as in the case of ISAs [55]. Under such conditions, IC offers powerful benefits by allowing access to valuable knowledge before it becomes available to those without such contacts [56]. Firms with greater IC are able to discover where useful resources are located and who can use such resources, as well as access information flows in a timely manner. The liability of foreignness is thus successfully overcome through the efficient identification of potentially useful resources and the search for competent partners [48].

In summary, we argue that IC provides important benefits to ISA participants through enhancement of learning capability, cooperative skill, and access to external resources. This argument leads to our first hypothesis:

Hypothesis 1. IC creates value for ISA partnering firms.

\subsection{The value of experience in ISAs}

Though the success of ISAs may depend on IC, we argue that alliance experience also plays an important role. First, the problems of incomplete contracts and the opportunistic behavior associated with ISAs shed light on the importance of inter-firm cooperative know-how [57]. The literature acknowledges that the main cost associated with strategic alliances arises out of the potential for opportunistic behavior by the partnering firms (e.g., [58,59]). Firms with interorganizational cooperative know-how may search out reliable partners, effectively anticipate contingencies, design suitable contracts and other bonding mechanisms to discourage opportunism, monitor partner behaviors, and lower the potential for failure [57]. The development of such collaborative know-how can occur either through direct collaborative experience or non-experiential methods like congenital learning, imitation, grafting, and searching [60]. However, because each alliance exists within the context of particular firms, each has its own routines governing how it responds to change [61]. Hence, collaborative know-how gleaned from external sources may not be easily internalized. In contrast, through incremental accumulation, experienced firms are expected to have greater opportunities to capture such know-how.

Further, expanding on evolutionary economics, Zollo [62] and Kale and Singh [63] proposed that firms' capabilities are developed on the basis of incremental learning and fine-tuning of relevant day-to-day activities. Pennings et al. [64] maintained that organizations evolve as they accumulate experiences, incrementally adjusting their reactions to similar problems while absorbing feedback about past decisions. Thus, as firms engage in more ISAs, they learn more about dissimilar environments and partnering firms. As their background in alliance experiences expands, firms will establish a more robust basis for alliance cooperation due to the increasing probability that the new situation is in a form familiar to the partnering firm. Thus, for firms experienced in alliance activities, a collective understanding regarding the execution of alliances is expected to emerge through the tacitly updated and refined alliance capability, enabling the firm to achieve continuous, incremental improvements in performance. We infer that 
as firms accumulate ISA experiences, their alliance performances are enhanced through advances in cooperative techniques and enhanced abilities to appropriate knowledge from partners.

Hypothesis 2. Prior experiences create value for ISA partnering firms.

\subsection{Interaction of alliance experience and IC}

While IC and experience are both important to the success of ISAs, their interaction may also play a crucial role in how a firm derives gains from ISAs. In general, in environments of low variation, the perceived need for change and the need for new information are likely to be weak. Alternatively, under conditions of high variation, the perceived need for efficient adjustment is likely to be stronger [65]. To cope with the rapidly changing environment, it is essential for a firm's capability to constantly evolve over time to keep pace with the changing market environment [65]. Cockburn et al. [66] found that though firms may have more or less identical original capabilities, their ultimate performances can vary significantly due to their differing capabilities in identifying and responding to environmental cues well in advance of performance-oriented payoffs. We argue that a "static" level of IC is insufficient for firms confronted with changing knowledge environments. Changing environments require firms to adjust and enrich their IC in a timely fashion.

To explain how IC interacts with the environment to advance its context, we use the model developed by Hussi and Ahonen [28], Hussi [29] and Hermans and Kauranen [30]. This model holds that a company's current performance depends primarily on its commercially exploitable intangibles (adjusted IC) which are generated by a continuous process of socialization, externalization, combination and internalization (SEIC) [67] to respond to the constantly changing environment through a balanced management of the interaction of human capital, structural capital and relational capital [28-30]. Each time the external environment sends a signal to the firm, it restructures its IC to accommodate this new shock. This initiates a SECI process through which the context of IC is adjusted and amplified. From the various interactions between IC and external environments, firms gradually adjust the context of IC, adapting to the changed environment to achieve competitive advantage. Specifically, this model highlights the importance of multiple interactions between IC and the environment, in the sense that generating such capability requires continuous accumulation of interac- tion experiences so that tacitly updated organizational knowledge becomes stored in routines and in new patterns of activities [50].

We argue that this interaction between IC and the environment is specifically important in the context of ISAs. Because ISAs often encounter great environment instability, ${ }^{2}$ IC must be aggressively adjusted to achieve a proactive adjustment to the changing environment. Alliance experiences perform as media for firms to continuously catch environmental signals. Focal alliance activity offers firms timely cues to identify essential capabilities to make the requisite adjustments. Take relational capital, for example. Alliance participants, when confronted with great environmental turbulence, rely on IC for information about whether and where complementary expertise may reside, and which firms offer access to valuable resources and capabilities (e.g., [5,68]). However, bundles of information are limitedly leveraged if firms lack further instructions to efficiently pick out the essential ones. Alliance experiences, through which environmental signals are timely conveyed, perform as an information filter to help firms identify essential resources. In turn, firms experienced in alliances could be more capable of utilizing the external information, speeding up the process of information accessing, partner searching, and thus accelerating the trial-and-error inter-firm learning process.

Take human capital for another example. While a skillful, well-educated employee may be capable of appropriating a partner's knowledge, the embeddedness of partner know-how requires individual workers to be involved in alliances over time [69]. Through socialization processes from various alliance experiences, the original knowledge base of employees can be enriched with later alliance experiences to achieve timely update and further refining. In this regard, experience makes an important contribution to the accumulation of IC.

The experiential fine-tuning mechanism, however, does not occur automatically and equivalently. Instead, its success is determined by firms' capability in leveraging IC to learn lessons from each alliance experience. Firms multiplying collaborative experiences when the alliance bandwagon effect prevails may rush into arrangements that are ill-conceived [57]. Alliance experiences in such situations are rarely digested and

\footnotetext{
${ }^{2}$ When technology shifts quickly and product life cycles are short, competition drives firms to develop capabilities faster than their rivals. Strategic alliances, which allow aids from partners, are effective vehicles for speeding capability development through access to complementary resources [68] or acquisition of partner's expertise [34]. Thus, ISAs are commonly found in environments characterized by great uncertainty and complexity.
} 
thus carry few useful lessons for the next deal. In contrast, a well-designed organizational structure offered by IC fosters the experiential learning process through making associations between a firm's past actions, the effectiveness of those actions, and future actions [15]. Thus, capabilities are built through a process that involves learning from past experience as a basis for present and future action, and the facilitation of feedback from prior and ongoing experiments in various parts of the firm [70]. The success of this learning process is critically dependent on the stock of IC.

In sum, IC constitutes the knowledge foundation of a firm, which it uses to accrue gains from alliance experiences. On the other hand, various experiences provide timely stimuli from the environment, with which firms are compelled to continuously update and reconfigure their IC in response to environmental changes. This iterative, mutually reinforcing process between IC and alliance experience leads to our final hypothesis.

Hypothesis 3. A firm's IC positively interacts with prior alliance experiences in the value creation of ISA.

\section{Sample and methodology}

\subsection{Sample selection and description}

A sample of US firms undertaking ISAs over the period 1989-2000 was collected from the Acquisitions and Alliances database of Securities Data Company. We eliminated alliances involving equity investments, such as joint ventures. For our purposes, alliances were required to include at least one US-based firm and one non-US partner. The initial announcement date (day 0) for each strategic alliance was confirmed by the Wall Street Journal Index. The ISA announcements had to meet the following criteria: (1) firms with other major announcements within ten days on either side of the announcement date were deleted from our sample set (to avoid any confounding events that could distort the measurement of the valuation effects of the alliances); (2) daily stock return information must be available from the Center for Research in Securities Prices (CRSP) returns files; and (3) company financial information must be available from the Compustat files.

Our final sample comprised 587 ISA announcements made by 305 US firms. Most of the ISAs (556) involved only one US firm. However, 20 ISAs involved two US firms in the same alliance, six involved three US firms, and five involved four US firms. Because we intended to investigate the wealth effects associated with IC and experience, the empirical analyses were based on firm level data. Thus, for an ISA involving three US firms, we treated each of those US firms as one observation, for a total of three observations. Consequently, we had 634 observations in the final sample. ${ }^{3}$

Table 1 presents the distribution of 587 ISA announcements. Panel A reports the sample distribution by year. The largest number of ISA announcements was 88 in 1999, followed by 77 in 1994. Panel B classifies the alliances by their intended purposes. Among the 587 ISA announcements, marketing or distribution constituted $30.66 \%$ of the sample. Research and/or development comprised $19.59 \%, 15.67 \%$ involved licensing, $12.27 \%$ involved technology transfer or systems integration, and $10.39 \%$ involved manufacturing.

Table 2 summarizes selected experience statistics for US partnering firms. We measured experience by the number of ISAs entered into by the firm prior to and including the ISA in question within the sample period. ${ }^{4}$ As shown in Panel A, the sample firms on average had 2.08 ISA transactions during the sample period. There was considerable variation in the experience measure across firms. While most of the firms (211) engaged in only one ISA, 46 firms were involved in three or more ISAs over the sample period. Some well-known firms are shown in Panel B: IBM (30 ISAs), Microsoft (29 ISAs), and American Telephone \& Telegraph (20 ISAs).

\subsection{Methodology}

Following Anand and Khanna [16] and Chen et al. [72], we used the wealth effect to measure the value creation of ISA announcements for partnering firms. This approach is based on the efficient market hypothesis [73], which argues that in an informationally efficient market, any new information will be incorporated into security prices. Thus, change in the price of a security would reflect the market's unbiased estimate of the economic value creation associated with that event [74]. Our calculation process is discussed below.

First, we employed standard event-study methods to examine aggregate stock price responses to announcements of ISAs. Event-study methodology

\footnotetext{
${ }^{3}$ We have tested the empirical results by deleting ISAs involving more than one US firm. The results are very similar.

${ }^{4}$ The experience measure is left-censored, since it only accounts for the deals entered into by the firm after 1989. However, this measure may be sensible since recent experience is more relevant in learning how to manage alliances than experience that have been consummated in the more distant past [16]. Benkard [71] provides empirical evidence in support of forgetfulness by firms in the aircraft industry.
} 
Table 1

Summarized statistics of international strategic alliances (ISAs)

Panel A. Annual distribution of ISA announcements

\begin{tabular}{lcr}
\hline Year of announcement & Number of announcements & Percent of total \\
\hline 1989 & 7 & 5 \\
1990 & 10 & 1.19 \\
1991 & 76 & 1.70 \\
1992 & 57 & 9.75 \\
1993 & 77 & 13.12 \\
1994 & 68 & 11.58 \\
1995 & 45 & 7.67 \\
1996 & 37 & 6.30 \\
1997 & 47 & 8.01 \\
1998 & 88 & 14.99 \\
1999 & 70 & 11.93 \\
2000 & 587 & 100 \\
Total & & \\
\hline
\end{tabular}

Panel B. Distribution of ISA announcements by type of cooperative agreements

\begin{tabular}{llrr}
\hline & Purposes of cooperative agreement & Number of announcements & Percent of total \\
\hline I. & Licensing & 92 & 15.67 \\
II. & Marketing or distribution & 180 & 30.66 \\
III. & Development or research & 115 & 19.59 \\
IV. & Technology transfer or systems integration & 72 & 12.27 \\
V. & Manufacturing & 61 & 10.39 \\
VI. & Various combinations of I-V & 67 & 11.41 \\
Total & & 587 & 100 \\
\hline
\end{tabular}

measures the effect of unexpected events on the expected stock returns of firms associated with that event. To measure the abnormal stock return to announcements of ISAs, we followed Brown and Warner [74] in using the market model to obtain estimates of expected returns. The market model depicts the return on a security as varying with the market portfolio return, which is adjusted for the security's risk factor, that is,

$E\left(R_{i t} \mid I_{t-1}, R_{\mathrm{mt}}\right)=\alpha_{i}+\beta_{i} R_{\mathrm{mt}}$,

where $E\left(R_{i t} \mid I_{t-1}, R_{\mathrm{mt}}\right)$ is the expected return on the $i$ th firm at time $t$, given the available information $\left(I_{t-1}\right)$ and the return on the market portfolio $\left(R_{\mathrm{mt}}\right) . \beta_{i}$ measures the risk or sensitivity of the firms' returns relative to the market portfolio, and $\alpha_{i}$ is the intercept. The abnormal return was calculated as the residual from the actual return and an expected return generated by the market model, with parameters, $\alpha_{i}$ and $\beta_{i}$, estimated over a period from 200 to 60 days before the initial announcements. We derived daily stock return information from the CRSP returns files. The value weighted NYSE $\backslash A M E X \backslash$ Nasdaq Index was used for measuring market returns.
Second, wealth effects were calculated by multiplying the announcement-period abnormal returns by the firm's market value of equity 10 trading days before the event announcement date. Anand and Khanna [16] have observed that announcement returns vary negatively with firm size. Thus, the measure of abnormal returns is biased by firm size. Conversely, the measure of wealth effect avoids this firm size bias, and more correctly reflects the changes in firm value. Thus, the measure of wealth effect can be viewed as a more attractive metric by which to measure the value creation of alliance announcements [16].

\subsection{Variables and measures}

\subsubsection{The measure of IC}

A firm's IC is generally defined as the "absolute" gap between firm's market value and book value in the literature (e.g., see $[24,25,31,75])$. It is the value recognized by the market but which fails to be counted in book because of the accounting treatment of intangibles. Some analysts, however, have expressed concern that the absolute definition of IC can be subject to the variations in book value treatment and the various imperfections 
Table 2

Selected experience statistics

\begin{tabular}{|c|c|c|}
\hline Number of ISAs & Number of firms & Total number \\
\hline 1 & 211 & 211 \\
\hline 2 & 48 & 96 \\
\hline 3 & 11 & 33 \\
\hline 4 & 13 & 52 \\
\hline 5 & 3 & 15 \\
\hline 6 & 2 & 12 \\
\hline 7 & 5 & 35 \\
\hline 8 & 2 & 16 \\
\hline 9 & 1 & 9 \\
\hline 10 & 1 & 10 \\
\hline 11 & 2 & 22 \\
\hline 12 & 1 & 12 \\
\hline 14 & 1 & 14 \\
\hline 18 & 1 & 18 \\
\hline 20 & 1 & 20 \\
\hline 29 & 1 & 29 \\
\hline 30 & 1 & 30 \\
\hline
\end{tabular}

Panel B. Illustrative sample firms undertaking multiple ISAs

\begin{tabular}{ll}
\hline Number of ISAs & Illustrative firms \\
\hline 8 & Bristol-Myers Squibb Co, Eastman Kodak Co Inc \\
9 & Continental Airlines Inc \\
10 & General Motors Corp \\
11 & Apple Computer Inc, Hewlett-Packard Co \\
12 & Intel Corp \\
14 & Delta Air Lines Inc \\
18 & Motorola Inc \\
20 & American Telephone \& Telegraph \\
29 & Microsoft Corp \\
30 & IBM Corp \\
\hline
\end{tabular}

of market valuations $[26,76] .^{5}$ In light of this possible distortion, Stewart [31] suggested using Tobin's $q$, a comparative measure of IC, to effectively diminish 'noise' from the environment.

Theoretically, Tobin's $q$ is defined as the ratio of the market value of the firm to the replacement value of its assets $[44,77,78]$. However, because of data availability, pseudo $q$, a simple measure of Tobin's $q$, has been widely accepted as a substitute for Tobin's $q$ (e.g., [79-81]). ${ }^{6}$ The $q$ variable is the ratio of the market value

\footnotetext{
${ }^{5}$ If IC is measured this way, then vibration of stock price implies drastic intellectual capital change. Moreover, since accounting rules offer alternative depreciation methods and tax deferral, book value could be somewhat subjectively decided, thereby intellectual capital is distorted accordingly.

${ }^{6}$ See, for example, Stewart [31], Holderness et al. [81] and Herremans and Isaac [78]. Chung and Pruitt [115] show that at least $96.6 \%$ of the variability of Tobin's $q$ (based on Lindenberg and Ross [82]) is explained by this simple measure of $q$.
}

to book value of assets for the fiscal years preceding the announcement, where the market value of assets is estimated as the book value of assets minus the book value of common equity plus the market value of common equity. In our study, pseudo $q$ was measured as the average $q$ for the 3 fiscal years prior to the announcement. ${ }^{7}$

\subsubsection{Control variables}

Even though a firm's IC, prior ISA experience, and the interaction of these two factors could be value enhancing, previous studies suggested other factors that also affect the wealth creation of inter-firm cooperation. Thus, we controlled for the effects of other prospective

\footnotetext{
${ }^{7}$ This follows the approach used in Lang et al. [83], Chen and Ho [80], and Chen et al. [84]. A 3-year average gives a better estimate of a firm's true $q$ [85] since the $q$ estimates may be noisy [85]. Our conclusions in this paper remain unchanged if the pseudo $q$ variable over the last year prior to the announcement is used.
} 
variables in this study. A review of ISA literature suggested influential factors, which we grouped into the following two categories: alliance/firm characteristics and industry characteristics.

\subsubsection{Alliance/firm characteristics}

First, we controlled for the types of alliance activities. Chan et al. [59] and Das et al. [86] maintained that while inter-firm cooperation benefit all firms, technical alliances that involve the transfer or pooling of technological knowledge may create more value than non-technical/marketing alliances. Alliances represent a particularly useful mechanism for accessing the competencies and resources required for complex technology. This framework of cooperation and exchange is valuable when the subject of exchange is highly specialized, intangible, inimitable or embedded in organization routines under which market-based trading is costly $[19,42,116]$. Following Chan et al. [59], technical alliances were those agreements that involve licensing, research or development agreements, technology transfer agreements, or combinations of the above, while non-technical alliances included cooperation activities such as marketing and manufacturing.

Second, we controlled for the economic status of ISA partner firms. Lummer and McConnell [87] suggested that the potential to exploit existing market imperfections in less developed countries functions as a contributing factor to the value creation of international cooperation. Thus, for US firms engaging in ISAs, the gain from exploiting market imperfections should be larger with partners from less developed countries than those from developed ones. Further, if the US partner has bargaining strength relative to the foreign partners from the less developed countries, it may be able to extract a larger portion of the total gains from the alliances [36]. We defined the economic status of partner countries using the World Bank classification.

Finally, we controlled for potential agency costs incurred when managers pursue personal interest at the expense of shareholders' wealth, based on Jensen [88]. Jensen [88] indicated that firms with higher free cash flow choose higher levels of debt in their capital structure as a credible pre-commitment to pay out the excess cash flow, thus lowering the expected costs of free cash flow. Jensen's theory suggests a positive relation between the market response to corporate announcements of investment decisions and the announcing firm's debt ratio. Consistent with this argument, Szewezyk et al. [89] and Chen and Ho [80], respectively, found supportive evidence in corporate $\mathrm{R} \& \mathrm{D}$ expenditures and capital expenditures. Lee and Wyatt [90] argued that the cost of the agency problem may explain the overall negative loss associated with international joint ventures. Thus, as previous research suggests, we used the debt ratio to control for the agency costs of free cash flow where the debt ratio is the long-term debt to total assets one year preceding the announcement date (e.g., $[80,88,89,91]$ etc.).

\subsubsection{Industry characteristics}

The first industry characteristic we controlled for was industry $R \& D$ intensity. Industry $R \& D$ intensity is measured as an indicator of the technological opportunity in an environment, which means the degree to which a firm's market demands or accepts product innovation $[92,93]$. ISAs, utilized by firms for the most part as ways to efficiently adjust themselves to cope with market variation, are supposed to be specifically important when the environment is characterized by greater technological opportunity. We measured industry R\&D intensity as the ratio of the 3-year average of industry $R \& D$ expenditures to average industry sales for the 3 years preceding the announcement $[94,95]$.

Next, we controlled for industry concentration. As the literature suggests, industry concentration is conventionally employed to define appropriability [96-98]. All else being equal, ISA firms in low-competition industries (high industry concentration) enjoy more profitable resource deployment than those in high-competition industries $[99,100]$. In a low-competition industry, the lower degree of rivals' sensitivity to a firm's actions indicates that the rent stream associated with firm's ISA is less vulnerable to rapid erosion [96]. Thus, the benefit from corporate strategy is believed to be positively associated with industry concentration. We used salesbased Herfindahl index to measure industry concentration, estimated as the squared sum of the market shares for firms in the same industry [97,98]. Industry classification was based on the four-digit SIC code.

The final industry variable was the firm's high/lowtech industry affiliation. Without equity participation, it is easier for ISA firms to establish new connections or disband previous networks. This inherent flexibility is especially important for firms operating under conditions of great environmental uncertainty [34]. Therefore, the experimental option of ISA is particular valuable for firms competing in high-tech industries that are characterized by quick changes in product design and process technologies and by rapid obsolescence of products [59]. Following Chan et al. [59,94], we used a dummy variable that equals one for high-tech 
industry, and zero otherwise to control for this variation. The industry classification was based on the Business Week schema [59].

\section{Empirical results}

\subsection{Descriptive statistics on sample firms}

Table 3 presents summary statistics for pseudo $q$, alliance and firm characteristics, and industry variables used in this study. Data was obtained from the Compustat files and the Wall Street Journal Index. Panel A, Table 3 shows that the mean (median) $q$ of our sample firms is 2.85 (1.85), with a standard deviation 2.54. Descriptive statistics of continuous controlling variables such as Debt ratio, Industry R\&D intensity, and Industry concentration are also shown in Panel A. Panel B, Table 3 shows that about $60 \%$ of the sample firms were involved in technological activities, $86 \%$ had partners from developed countries, and $65 \%$ operated in hightech industry. The number of observations differs for each variable due to data availability.

\subsection{Wealth effect for the entire sample}

Table 4 shows the results of announcement-period value creation for ISA partnering firms. Results of various event windows are presented in Panel A, Table 4. On both the announcement date (day 0 ) and the date previous to the announcement date (day-1), ISA firms receive strongly positive abnormal returns. Daily average abnormal returns of the two days are $0.36 \%(t$-statistic $=1.98)$ and $1.15 \%(t$-statistic $=5.46)$, respectively, both statistically significant using two-tailed $t$-tests. The median abnormal returns for day 0 ( $p$-value $=0.07$ ) and day- 1 $(p$-value $<0.01)$ are also significantly greater than zero using the Wilcoxon Signed Rank test, suggesting that the positive market reactions are not driven by outlying observations. No significant abnormal returns are observed preceding and following the announcement period. This indicates that the market reactions are primarily caused by announcements of ISAs. Accordingly, we use the 2-day (day-1, day 0) cumulative abnormal returns to compute the dollar wealth change. Specifically, the measure of dollar wealth effect is obtained by multiplying the 2-day cumulative abnormal returns by the market value of equity 10 days before the associated ISA announcement.

Summary statistics of the event windows $(-1,0)$ for cumulative abnormal returns and dollar wealth effects are stated in Panel B, Table 4. The mean (median) wealth effect of ISA announcements is \$24.19 million
(\$0.42 million), with a standard deviation of \$245.15 million. These findings are smaller in magnitude than those observed by Anand and Khanna [16] for joint venture announcements - a mean (median) wealth effect of $\$ 44.06$ million (\$0.76 million) with a standard deviation of $\$ 909.14$ million.

\subsection{Wealth effect comparison based on subsamples}

Panel A, Table 5 compares the wealth effect of partnering firms based on the firm's level of IC. Hypothesis 1 infers that the value creation of ISA activities by firms with higher levels of IC should be greater than that by firms with lower levels of IC. The sample was stratified based on whether a firm's pseudo $q$ was greater than the sample median. Our findings show that the wealth effect of high- $q$ partnering firms is significantly greater than zero both in $t$-test $(t$-statistic $=2.35)$ and Wilcoxon test $(p$-value $=0.06)$. In contrast, the market reaction for low- $q$ partners is not only smaller in magnitude, it is also not significantly different from zero. The mean difference test indicates that high- $q$ firms achieve significantly higher gains than low- $q$ firms $(t$-statistic $=2.21)$. This evidence thus provides preliminary support for Hypothesis 1 .

Next, we examine whether prior experience adds value to firm performance in ISAs. Panel B, Table 5 shows the effect of ISA experience on value gains of ISAs. ISA experienced firms are those with more than three ISA activities in the sample period. ${ }^{8}$ The results show that the mean wealth effect for the ISA experienced subsample is significantly greater than zero $(t$-statistic $=2.43)$. By contrast, the mean wealth effect for ISA inexperienced firms is not significantly different from zero. Further, the mean difference in wealth effect between the two sub-groups is statistically significant using a simple $t$-test $(t$-statistic $=2.34)$. The results lend some support for Hypothesis 2, suggesting that experience might contribute to the value creation of ISAs.

Finally, Hypothesis 3 is examined with a $2 \times 2$ table based on pseudo $q$ and ISA experience simultaneously. Hypothesis 3 predicts the presence of an interaction effect of a firm's IC and experience in the wealth creation of ISAs. Panel C, Table 5 shows that

\footnotetext{
${ }^{8}$ It takes time for firms to digest the lessons from prior experience. Haunschild et al. [101] argued that managers cannot carefully evaluate deals that occur in quick succession. Anand and Khanna [16] found that experience with joint ventures began to create positive value after the third experience. Thus, we use three prior ISAs as the criteria for ISA-experienced firms. However, our findings do not change using 1,2 and 4 prior experiences as the threshold criteria.
} 
Table 3

Descriptive statistics on sample alliances

Panel A. Summary statistics on continuous variables

\begin{tabular}{llrrr}
\hline Variables & Total number & Mean & Median & Standard deviation \\
\hline Pseudo $q$ & 510 & 2.85 & 1.85 & 2.54 \\
Debt ratio (\%) & 581 & 14.32 & 9.57 & 17.60 \\
Industry R\&D intensity & 524 & 0.08 & 0.06 & 0.07 \\
Industry concentration & 568 & 0.20 & 0.14 & 0.18 \\
\hline
\end{tabular}

Panel B. Summary statistics on dichotomous variables

\begin{tabular}{llll}
\hline Variables & Total number & Positive number & Positive percentage \\
\hline Tech-alliances dummy & 634 & 377 & 59.46 \\
Economic-status-of-partners dummy & $627^{\mathrm{a}}$ & 538 & 85.80 \\
High-tech industry dummy & 414 & 220 & 65.30 \\
\hline
\end{tabular}

Pseudo q: The average market-to-book value of asset for 3 years preceding the announcement, where market value of asset is calculated as the book value of assets minus the book value of common equity plus the market value of common equity.

Debt-ratio: The ratio of long-term debt to total asset 1 year preceding the announcement date.

Industry $R \& D$ intensity: The ratio of the 3 -year average of industry $R \& D$ expenditures to average industry sales for the 3 years preceding the announcement.

Industry concentration: Sale-based Herfindahl Index, estimated as the squared sum of the fractions of industry sales 1 year preceding the announcement.

Tech-alliances dummy $=1$ if the ISA agreements involve licensing, research or development agreements, technology transfer agreements, or combinations of the above, and zero otherwise.

Economic-status-of-partners dummy $=1$ for firm's ISA partner from developed countries and zero otherwise.

High-tech industry dummy $=1$ if the participant firm is in high-technology industry and zero if it's affiliated to low-technology industry, where high/low technology industry classifications are based on SIC codes and Business Week's classification scheme.

${ }^{a}$ There are seven ISAs involving multiple partners from both developed and developing countries.

in the high-q/experienced subsample, both the mean and median wealth effects are significantly greater than zero $(t$-statistic $=2.43$ for $t$-test, and $p$-value $=0.02$ for Wilcoxon test). In contrast, neither the mean nor the median wealth effect for high-q/inexperienced firms is significantly different from zero. The mean difference between these two subsamples is statistically significant $(t$-statistic $=2.37)$. This result is not sensitive to the assumption of distribution, since it also holds for the nonparametric Kruskal-Wallis test ( $p$-value $=0.05$ ). High- $q$ firms, therefore, significantly benefit from experiential learning from prior ISA activities.

For the low- $q$ subsample, however, the effect of experience observed in high- $q$ firms cannot be similarly found. Wealth effects for both low-q/experienced and low-q/inexperienced subsamples are not significantly different from zero under either the $t$-test or Wilcoxon test. There was also no significant difference in the wealth effect between the two subsamples. These findings suggest that experience is valuable only for firms with greater IC.

Further, the interaction effect hypothesis predicts that high-q/experienced firms benefit most from the ISA activities, and hence, are expected to have the largest announcement-period wealth effect. Consistent with this hypothesis, the results show that the subsample of high- $q$ /experienced firms has a significant average (median) wealth effect of 137.48 (42.75) million, the largest among the four subsamples. Conversely, the wealth effects of other subsamples (high-q/inexperienced, low-q/experienced and low-q/inexperienced firms) are much lower and statistically insignificant. Collectively, the findings in Panel $\mathrm{C}$, Table 5 suggest that the experience effect of ISA activities are not consistent across firms. The positive impact of experience on ISA performance occurs primarily in firms with ample IC. Since high IC firms are more capable of capturing and storing the lessons from previous ISA experiences, they make greater progress as experience accumulates. Hypothesis 3 is thus preliminarily supported.

\subsection{Cross-sectional regression analysis}

Although the results in Table 5 support the notion that the value creation of ISAs is strongly influenced by IC, prior alliance experiences, and their interaction, these tests do not control for the impacts of other influential factors. To take into account the effect of these factors, we constructed a multivariate regression model. 
Table 4

Wealth effect and event study results

\begin{tabular}{|c|c|c|c|c|c|}
\hline $\begin{array}{l}\text { Period relative to } \\
\text { the announcement }\end{array}$ & $\begin{array}{l}\text { Mean abnormal } \\
\text { return }(\%)\end{array}$ & $t$-statistic & $\begin{array}{l}\text { Median abnormal } \\
\text { return }(\%)\end{array}$ & $\begin{array}{l}p \text {-value for the } \\
\text { Wilcoxon } \\
z \text {-statistic }\end{array}$ & $\begin{array}{l}\% \text { of positive } \\
\text { abnormal returns }\end{array}$ \\
\hline$(-30,-2)$ & 1.29 & 1.57 & 0.51 & 0.28 & 52.21 \\
\hline$(-20,-2)$ & 0.92 & 1.40 & 0.64 & 0.26 & 53.47 \\
\hline$(-10,-2)$ & 0.52 & 1.16 & -0.28 & 0.78 & 47.95 \\
\hline$(-1)$ & 1.15 & $5.46^{* * *}$ & 0.25 & $<0.01^{* * *}$ & 54.57 \\
\hline (0) & 0.36 & $1.98^{* *}$ & 0.14 & $0.07 *$ & 54.10 \\
\hline (1) & 0.22 & 1.56 & -0.05 & 0.95 & 48.58 \\
\hline$(1,10)$ & -0.05 & -0.12 & 0.27 & 0.90 & 51.89 \\
\hline$(1,20)$ & -0.62 & -1.01 & -0.15 & 0.40 & 49.53 \\
\hline$(1,30)$ & -0.92 & -1.24 & -0.35 & 0.25 & 49.21 \\
\hline
\end{tabular}

Panel B. Summary statistics of CAR $(-1,0)$ and wealth effects

\begin{tabular}{lrlrrr}
\hline & Mean & Median & S.D. & Minimum & Maximum \\
\hline CAR $(-1,0)(\%)$ & 1.51 & 0.42 & 7.06 & -32.00 & 56.89 \\
Wealth effects & 24.19 & 0.42 & 245.15 & -1514.25 & 2084.95 \\
(millions) & & & & & \\
\hline
\end{tabular}

The sample consists of 634 firm events of international strategic alliances announced by US firms over the period 1989-2000. Wealth effects are calculated by multiplying the cumulative abnormal returns in the event window (day-1, day 0 ) by the firm's market value of equity 10 trading days before the event announcement date, where cumulative abnormal returns are estimated using the standard market model procedure with the parameters estimated for the period 200 days to 61 days before the announcement. Firm size is measured by the market value of equity calculated as the number of common shares outstanding multiplied by the share price for the fiscal year preceding the announcement. Day 0 in event time is the date of the publication in which the company's initial announcement appears. “***" and “*” represent $1 \%$ and $10 \%$ significance levels using a two-tailed test, respectively.

Table 6 presents the results of regression analyses including all the potentially influential variables. Specifically, alliance and firm characteristics such as the type of alliance activity, economic status of partners, agency costs, and industry characteristics such as industry R\&D intensity, industry concentration, and firm's high/low-tech industry affiliation are controlled. We used continuous measures of experience, pseudo $q$, and their interaction term to test the hypotheses. Because the interaction term is constructed from IC and experience, we applied the centering approach in the regression to avoid the potential bias of multicollinearity [114]. The number of observations varies across the regression models due to variations in data availability.

Model 1 shows that the dollar wealth changes of ISA announcements are significantly and positively related to pseudo $q$. The result holds even when we include the control variables in model 2 . These findings are consistent with those in Panel A, Table 5, and provide strong support for Hypothesis 1. Models 3 and 4 investigate the effect of experience. The results of both models show that ISA experience is positively and significantly associated with dollar wealth change from ISA announce- ments. These results confirm the findings in Panel B, Table 5, and Hypothesis 2 is accordingly supported. Model 5 tests Hypothesis 3 by adding the interaction of experience and pseudo $q$ into the regression analysis. The result shows that experience, pseudo $q$, and their interaction all have important positive impacts on the value creation of ISAs since their associated coefficients are all statistically different from zero. The results conform to those reported in Panel C, Table 5. Hypothesis 3 is thus supported.

To test the robustness of our results, we tested other measures of IC and experience. Specifically we redid the regression analysis by using a dummy variable approach that includes a dummy for IC that equals one if the value of pseudo $q$ ratio is greater than the sample median, and zero otherwise. Similarly, we used a dummy of experience that equals one when the announcing firms have more than three prior experiences in ISAs, and zero otherwise. The results of the dummy approach are very similar to those in Table 6. In addition, to test if the results are subject to the potential bias of data skewness, we normalized each variable and redid the regression analysis using the normalized 
Table 5

Mean and median 2-day announcement period wealth effects for subsamples stratified according to pseudo $q$ and cash flow

Panel A. Analysis of subsamples based on pseudo $q$

\begin{tabular}{lll}
\hline High $q$ & Low $q$ & Mean difference \\
\hline Mean wealth effect $=55.55$ & Mean wealth effect $=2.78$ & 52.77 \\
Median wealth effect $=0.69$ & Median wealth effect $=0.18$ & $(2.21)^{* *}$ \\
$\left(2.35^{* *}, 0.06,256\right)$ & $(0.74,0.85,254)$ & {$[0.19]$}
\end{tabular}

Panel B. Analysis of subsamples based on ISA experience

\begin{tabular}{lll}
\hline Experienced & Inexperienced & Mean difference \\
\hline Mean wealth effect $=75.58$ & Mean wealth effect $=2.36$ & 73.22 \\
Median wealth effect $=1.63$ & Median wealth effect $=0.34$ & $(2.34)^{* *}$ \\
$\left(2.43^{* *}, 0.09,189\right)$ & $(0.60,0.04,445)$ & {$[0.38]$} \\
\hline
\end{tabular}

Panel C. Analysis of subsamples based on ISA experience and pseudo q

\begin{tabular}{llll}
\hline & Experienced & Inexperienced & Mean difference \\
\hline High $q$ & Mean wealth effect $=137.48$ & Mean wealth effect $=1.28$ & 136.20 \\
& Median wealth effect $=42.75$ & Median wealth effect $=0.17$ & $(2.37)^{* *}$ \\
& $\left(2.43^{* *}, 0.02,102\right)$ & $(0.13,0.68,154)$ & {$[0.05]$} \\
Low $q$ & Mean wealth effect $=3.08$ & Mean wealth effect $=2.62$ & 0.46 \\
& $\begin{array}{l}\text { Median wealth effect }=-0.98 \\
(0.35,0.65,86)\end{array}$ & $\begin{array}{l}\text { Median wealth effect }=0.26 \\
(0.78,0.42,168)\end{array}$ & $(0.05)$ \\
& & $(0.46]$ &
\end{tabular}

ISA inexperienced (experienced) firms: those with their ISA activities within (more than) the first three times.

High- $q$ (low- $q$ ) firms: those with pseudo $q$ above (below) the median for the whole sample.

For each cell, we report the mean wealth effects, the median wealth effects, and in parentheses, the $t$-statistic, the $p$-value for the Wilcoxon $z$-statistic and the number of observations.

For the comparison of means, we report mean difference, the $t$-statistic in parentheses and the $p$-value for the non-parametric Kruskal-Wallis statistic in square brackets.

“***”, “**" and "*” represent $1 \%, 5 \%$ and $10 \%$ significance levels using a two-tailed test, respectively.

values. The results remained the same. This suggests that our findings are not seriously biased by the problem of skewed data.

In sum, the findings provide strong support that while ISA participating firms can benefit from their IC and prior experiences, the realization of value maximization from ISAs greatly depends on the joint influence of these two factors.

\section{Discussion and conclusion}

\subsection{Discussion}

Recently researchers have emphasized the importance of a firm's absorptive capacity in diverse and complex organizational phenomena. It should be noted that although the concept of IC shares some similarities with the concept of absorptive capacity, they are not completely comparable. Zahra and George [102] argued that absorptive capacity exists as two subsets of potential and realized absorptive capacities. Potential absorptive capacity denotes a firm's capability to identify, acquire, understand and process external expertise, while realized absorptive capacity refers to a firm's capability to transform and exploit the acquired knowledge. From the perspective of IC, these concepts of absorptive capacity are similar to the components of human capital and structural capital that emphasize the resources and capability within a firm. Nevertheless, absorptive capacity has less overlap with the concept of another important component of IC, relational capital, since certain elements associated with relational capital are not made explicit in the concept of absorptive capacity. First, the advantage that networking embedded in relational capital confers upon a firm is a social legitimacy that may provide valuable access to resources outside the boundary of a firm [117]. Information gained from relational capital may speed up the learning process from prior experience and enable better development of cooperative know-how in managing inter-firm collaboration. Consequently, firms with better relational capital are more likely to better realize the potential synergy of alliances. Second, better relational capital will not only enhance a firm's own reputation 
Table 6

Cross-sectional regression analyses of ISA value creation

\begin{tabular}{|c|c|c|c|c|c|}
\hline \multirow[t]{2}{*}{ Variable } & \multicolumn{5}{|l|}{ Models } \\
\hline & 1 & 2 & 3 & 4 & 5 \\
\hline Intercept & $\begin{array}{l}-51.40 \\
(-2.94)^{* * *}\end{array}$ & $\begin{array}{l}30.41 \\
(0.72)\end{array}$ & $\begin{array}{l}-38.72 \\
(-3.46)^{* * *}\end{array}$ & $\begin{array}{l}63.46 \\
(2.04)^{* *}\end{array}$ & $\begin{array}{l}32.65 \\
(0.82)\end{array}$ \\
\hline \multicolumn{6}{|l|}{ Explanatory variables } \\
\hline Pseudo $q$ & $\begin{array}{l}28.31 \\
(6.17)^{* * *}\end{array}$ & $\begin{array}{l}24.89 \\
(5.18)^{* * *}\end{array}$ & & & $\begin{array}{l}9.89 \\
(1.94)^{*}\end{array}$ \\
\hline Experience & & & $\begin{array}{l}15.43 \\
(9.63)^{* * *}\end{array}$ & $\begin{array}{l}12.91 \\
(8.70)^{* * *}\end{array}$ & $\begin{array}{l}9.05 \\
(4.93)^{* * *}\end{array}$ \\
\hline Pseudo $q *$ Experience & & & & & $\begin{array}{l}1.21 \\
(3.12)^{* * *}\end{array}$ \\
\hline \multicolumn{6}{|l|}{ Alliance and firm characteristics } \\
\hline Economic-status-of-partners dummy & & $\begin{array}{l}-79.80 \\
(-2.75)^{* * *}\end{array}$ & & $\begin{array}{l}-64.06 \\
(-2.67)^{* * *}\end{array}$ & $\begin{array}{l}-68.29 \\
(-2.49)^{* *}\end{array}$ \\
\hline Tech-alliances dummy & & $\begin{array}{l}-8.31 \\
(-0.39)\end{array}$ & & $\begin{array}{l}-15.10 \\
(-0.87)\end{array}$ & $\begin{array}{l}-3.13 \\
(-0.16)\end{array}$ \\
\hline Debt ratio & & $\begin{array}{l}8.52 \\
(0.12)\end{array}$ & & $\begin{array}{l}-20.43 \\
(-0.42)\end{array}$ & $\begin{array}{l}12.58 \\
(0.18)\end{array}$ \\
\hline \multicolumn{6}{|l|}{ Industry characteristics } \\
\hline Industry $R \& D$ intensity & & $\begin{array}{l}-96.67 \\
(-0.52)\end{array}$ & & $\begin{array}{l}254.16 \\
(2.01)^{* *}\end{array}$ & $\begin{array}{l}78.52 \\
(0.44)\end{array}$ \\
\hline Industry concentration & & $\begin{array}{l}3.00 \\
(0.06)\end{array}$ & & $\begin{array}{l}-59.05 \\
(-1.29)\end{array}$ & $\begin{array}{l}-12.66 \\
(-0.24)\end{array}$ \\
\hline High-tech industry dummy & & $\begin{array}{l}19.76 \\
(0.75)\end{array}$ & & $\begin{array}{l}-36.21 \\
(-1.61)\end{array}$ & $\begin{array}{l}-21.50 \\
(-0.83)\end{array}$ \\
\hline Adjusted $R^{2}$ & 0.068 & 0.080 & 0.127 & 0.144 & 0.186 \\
\hline$F$-statistic & $38.08^{* * *}$ & $6.33^{* * *}$ & $92.68^{* * *}$ & $13.05^{* * *}$ & $11.86^{* * *}$ \\
\hline No. of observations & 510 & 428 & 634 & 503 & 428 \\
\hline
\end{tabular}

Economic-status-of-partners dummy $=1$ for firm's ISA partner from developed countries and zero otherwise.

Tech-alliances dummy $=1$ if the ISA agreements involve licensing, research or development agreements, technology transfer agreements, or combinations of the above, and zero otherwise.

Debt-ratio: The ratio of long-term debt to total asset 1 year preceding the announcement date.

Industry $R \& D$ intensity: The ratio of the 3 -year average of industry R\&D expenditures to average industry sales for the 3 years preceding the announcement.

Industry concentration: Sale-based Herfindahl Index, estimated as the squared sum of the fractions of industry sales 1 year preceding the announcement.

High-tech industry dummy $=1$ if the participant firm is in high-technology industry and zero if it's affiliated to low-technology industry, where high/low technology industry classifications are based on SIC codes and Business Week's classification scheme.

The $t$-values are in parentheses. "***", “**" and " *" represent $1 \%, 5 \%$ and $10 \%$ significance levels using a two-tailed test, respectively.

as a desirable partner [103], it may also foreclose partnering opportunities from competing rivals [118].

The function of IC emphasized in this study also differs from absorptive capacity in another important way. Prior research on absorptive capacity has focused on the question of how a firm's absorptive capacity is able to better facilitate knowledge learning from partners in inter-firm collaboration [49]. Although this study also discusses the importance of IC in knowledge learning, we further emphasize the role of IC in developing the capability to manage fragile inter-firm collaborations. This capability is valuable in establishing a stable inter- firm relationship crucial to knowledge learning and resource exchange among partners. Furthermore, the concepts and empirical evidence in this study emphasize the importance of interaction between IC and experience. Experience generates greater influence when there exists a higher level of IC that allows firms to better capture and store lessons from prior experience. At the same time feedback from prior experience increases the stock of IC, providing further benefits to the firm. The evidence shows that the interaction effect is essential in the value creation of ISAs. This interaction effect, however, is not an important thesis of absorptive capacity. 
In this study, Tobin's $q$ is employed as our proxy for IC. This measure, however, is a crude measure of IC, and is not able to distinguish the specific impact associated with each of three elements of IC. In fact, there is a wealth of literature on how to measure the final products of IC, such as percentage of loyal customers, number of patents, employee turnover, and numerous survey questionnaires (e.g., see [30,104]). However, caution should be exercised in using these internal measures as the arbitrary choice of IC indicators may lead to subjectivity biases [44,77]. Further, this literature has been criticized for providing too much information and too many measures, thus making the analysis of IC difficult [105]. In spite of these concerns, internal measures of IC greatly aid managers with a strategic implication through the disaggregating of IC into categories, thus providing guidelines for developing and realizing IC potential $[24,25,44,106]$. In contrast, crude measures of IC, such as Tobin's $q$, seem generic and parsimonious. Therefore, the relationship between a firm's IC, prior experiences, and value creation of ISAs found in this study can be taken as a point of departure for further investigation of the influence of IC at the level of the individual element. We leave this for future research.

The other limitation of Tobin's $q$ as the IC measure is related to the accounting treatment. GAAP offers several alternative legal conventions in bookkeeping, such as treatment of $R \& D$ expenses, depreciation methods and tax deferral. These various bookkeeping approaches lead to differing figures for a given firm's book value even when firms are essentially identical in their financial conditions.

Finally, we would like to discuss the measure of alliance performance. Reviewing the literature, there does not exist a consensus about the proper measures of alliance performance $[9,22,107]$. Non-equity alliances are essentially pure-contract-type agreements for which performance as judged by traditional accounting and financial figures seems inappropriate, due to the difficulty of delineating the portion of performance attributable to a particular alliance [23,108]. Recently, event study methodology has been used to assess alliance success and the economic value created by alliances (e.g., see $[16,23,59,108,109])$. This methodology examines the value implications of corporate events from the perspectives of shareholder wealth (for a review, see [74,110]). Yet some researchers are concerned that the initial stock market responses to the announcement of a specific event may not truly reflect the actual long-run performance of firms [111,112]. Countering this doubt, recent research has provided evidence of a strong link between the initial stock market reaction and the long-run bene- fits realized by the firm. ${ }^{9}$ Additionally, the use of event study methodology seems appropriate in this context as alliances represent major 'events' and hence are likely to impact the stock price of the focal firms. Thus, given the controversy surrounding performance measures in alliance research and the logistical challenges of collecting the variety of data necessary to assess performance $[22,107],{ }^{10}$ using share price changes as indicators of firm performance in alliances appears promising. Further research may revisit the issue we address with other performance measures when the data is available.

\subsection{Conclusion}

In this paper we address three questions. First, we investigate whether a firm's stock of IC affects the performance in ISAs. We argue that the uncertainty and instability of ISAs offers a perfect setting to test the importance of IC. Second, we explore whether firms participating in ISAs benefit from prior experiences. Previous literature has examined the learning effect in various types of inter-firm cooperation. Nevertheless, the question of whether firms learn from their alliance experiences in the domain of international, non-equity involved strategic alliances has never been investigated. Our study directly addresses this issue. Finally, we examine the interaction effect of a firm's IC in the process of experiential learning from previous alliance experiences. Previous literature on the issue of inter-firm experiential learning has acknowledged that the value of alliance experiences varies greatly from firm to firm. However, work on why experience creates value for some firms, but not for others, is lacking. To address this gap, this study introduces the concept of IC as a mediating construct between alliance experience and firm value creation, thereby bringing together research streams from the resource-based perspective, knowledge-based perspective, dynamic capability, evolutionary economics and organizational learning to create a more comprehensive and integrative conception of ISA value creation. Findings from our study may have implications for research into IC and strategic alliances, as well as for practitioners.

Our results show that, in general, firms with greater stocks of IC receive stronger wealth gains from ISA activities. This suggests that cultivating IC is crucial in

\footnotetext{
${ }^{9}$ Supporting evidence has been found in study of mergers and acquisitions [113], joint ventures [108], and strategic alliances [23].

${ }^{10}$ Contractor and Lorange [107] stated that even with efforts to control for response biases, the survey data usually represent a minority (generally between $15 \%$ and $30 \%$ ) of the target partners.
} 
deriving the greatest benefits from alliance activities. It is thus advisable for firms participating in ISAs, which are increasingly popular, yet prone to high failure rates, to constantly enhance their stocks of IC in each of its three dimensions of structural capital, human capital, and relational capital.

Next, the empirical findings indicate a positive influence of ISA experience on firm performance. Firms engaging in non-equity alliances strongly benefit from prior experiences through which cooperative knowhow is developed. The development and refinement of cooperative know-how may be more important in shaping the performance of non-equity, as opposed to equity-based collaborations, precisely because the former lack the coordination potential and alignment of incentives available through equity government. Our findings indicate that managers of non-equity alliances should prioritize the aggressive development of cooperative know-how through alliance experience accumulation.

Finally, our findings indicate that the relationship between experience and performance is more complicated than that documented in previous literature. The form of this relationship is positively moderated by a firm's stocks of IC. The results suggest that firms do not homogeneously learn from previous experience. Firms with a higher level of IC make significant progress as they accumulate alliance experiences, whereas firms with lower levels of IC fail to do so. Therefore, experience alone does not ensure that a firm can benefit from ISA cooperation. Experience is valuable only if its salutary lessons are internalized and translated into know-how to guide future actions. IC, as suggested by this study, is an important mechanism through which firms become more efficient in internalizing lessons learnt from prior experiences.

Although this study underscores the importance of a firm's IC, experience, and the interaction between them in generating benefits from ISAs, we believe that the insights this study provides are not limited to the alliance context. Instead, they could be generalized to any broader organizational setting, especially those characterized by high uncertainty and complexity, where IC, experience, and their interaction can play important roles in determining success.

\section{References}

[1] Das TK, Teng BS. A resource-based theory of strategic alliances. Journal of Management 2000;26:31-61.

[2] Inkpen AC. Learning through joint ventures: a framework of knowledge acquisition. Journal of Management Studies 2000;37:1019-43.
[3] Slater SF, Narver JC. Market orientation and learning orientation. Journal of Marketing 1995;59(3):63-74.

[4] Sinkula JM, Baker WE, Noordewier T. A framework for marketbased organizational learning: linking values, knowledge, and behavior. Journal of Academy and Marketing Science 1997;25(4):305-18.

[5] Hamel G. Competition for competence and inter-partner learning within international strategic alliances. Strategic Management Journal 1991;12:83-104.

[6] Sarkar MB, Echambadi R, Cavusgil ST, Aulakh P. The influence of complementarity, compatibility, and relationship capital on alliance performance. Journal of Academic Marketing and Science 2001;29(4):358-73.

[7] Porter M, Fuller M. Coalitions and global strategy, competition in global industries. Boston, MA: Harvard Business School; 1986.

[8] Mowery DC. International collaborative ventures in US manufacturing. Cambridge, MA: Ballinger; 1988.

[9] Parkhe A. Inter-firm diversity, organizational learning and longevity in global strategic alliances. Journal of International Business Studies 1991;22:579-602.

[10] Shan W, Hamilton W. Country-specific advantage and international cooperation. Strategy Management Journal 1991;12:419-32.

[11] Harrigan KR. Managing for joint venture success. New York: Praeger; 1985.

[12] Arino A, de la Torre J. Learning from failure: towards an evolutionary model of collaborative ventures. Organization Science 1998;9(3):306-25.

[13] Kale P, Singh H, Perlmutter H. Learning and protection of proprietary assets in strategic alliances: building relational capital. Strategic Management Journal 2000;Special issue, 21:217-37.

[14] Alliance Analyst. Measuring alliance performance. Philadelphia, PA: New Cap Communications; 1998.

[15] Fiol CM, Lyles MA. Organizational learning. Academy of Management Review 1985;10:803-13.

[16] Anand B, Khanna T. Do firms learn to create value? The case of alliances. Strategic Management Journal 2000;21(3): 295-316.

[17] Jensen M, Meckling W. Specific and general knowledge, and organizational structure. In: Werin L, Wijkander H, editors. Main currents in contract economics. Oxford: Blackwell; 1991. p. 251-74.

[18] Telser LG. A theory of self-enforcing agreements. Journal of Business 1980;53:27-41.

[19] Williamson OE. The economic institutions of capitalism. New York: Free Press; 1985.

[20] Kumar R, Nti KO. Differential learning and interaction in alliance dynamics: a process and outcome discrepancy model. Organization Science 1998;9(3):356-66.

[21] Dyer JH. Specialized supplier networks as a source of competitive advantage: evidence from the auto industry. Strategic Management Journal 1996;7:271-91.

[22] Gulati R. Alliances and networks. Strategic Management Journal 1998;19(4):293-318.

[23] Kale P, Dyer JH, Singh AH. Alliance capability, stock market response, and long-term alliance success: the role of the alliance function. Strategic Management Journal 2002;23:747-67.

[24] Edvinsson L, Malone M. Intellectual capital: realizing your company's true value by finding its manpower. New York: Harper Collins; 1997. 
[25] Sveiby K. The new organizational wealth: managing and measuring knowledge based assets. San Francisco, CA: Berrett Koehler; 1997.

[26] Dzinkowski R. The measurement and management of intellectual capital. Management Accounting 2000;February: 32-6.

[27] MERITUM Project. Guidelines for managing and reporting on intangibles (intellectual capital report). Fundación Airtel Móvil, Madrid, 2002.

[28] Hussi T, Ahonen G. Managing intangible assets-a question of integration and delicate balance. Journal of Intellectual Capital 2002;3(3):277-86.

[29] Hussi T. Reconfiguring knowledge management-combining intellectual capital, intangible assets and knowledge creation. Journal of Knowledge Management 2004;8(2):36-52.

[30] Hermans R, Kauranen I. Value creation potential of intellectual capital in biotechnology-empirical evidence from Finland. R\&D Management 2005;35(2):171-85.

[31] Stewart T. Intellectual capital: the new wealth of nations. New York: Doubleday Dell Publishing Group; 1997.

[32] Wang WY, Chang C. Intellectual capital and performance in causal models. Journal of Intellectual Capital 2005;6(2): 222-36.

[33] Hayton JC. Competing in the new economy: the effect of intellectual capital on corporate entrepreneurship in hightechnology new ventures. R\&D Management 2005;35(2): 137-55.

[34] Mody A. Learning through alliances. Journal of Economic Behavior and Organization 1993;20:151-70.

[35] Barkema HG, Vermeulen F. What differences in the cultural backgrounds of partners are detrimental for international joint ventures?. Journal of International Business Studies 1997;28(4):845-64.

[36] Gupta A, Misra L. The value of experiential learning by organizations: evidence from international joint ventures. The Journal of Financial Research 2000;23(1):77-102.

[37] Merchant H, Schendel D. How do international joint ventures create shareholders value?. Strategic Management Journal 2000;21:723-37.

[38] Pisano GP. Using equity participation to support exchange: evidence from the biotechnology industry. Journal of Law, Economics and Organization 1989;5:109-26.

[39] Van de Ven, Andrew H. On the nature formation and maintenance of relations among organizations. Academy of Management Review 1976;1:24-36.

[40] Harrigan KR. Strategic alliances and partner asymmetries. Management International Review 1988;28:53-72.

[41] Pena I. Intellectual capital and business start-up success. Journal of Intellectual Capital 2002;3(2):180-98.

[42] Barney J. Strategic factor markets: expectations, luck and business strategic. Management Science 1986;32:1231-41.

[43] Grant RM. Prospering in dynamically-competitive environments: organizational capacity as knowledge integration. Organization Science 1996;7:375-88.

[44] Roos J, Roos G, Dragonetti NC, Edvinsson L. Intellectual capital: navigating the new business landscape. London: Macmillan Press; 1997.

[45] Brown JS, Duguid P. Organizing knowledge. California Management Review 1998;40(3):90-111.

[46] Tushman ML. Special boundary roles in the innovation process. Administrative Science Quarterly 1977;22:587-605.
[47] Cohen WM, Levinthal DA. Absorptive capacity: a new perspective on learning and innovation. Administrative Science Quarterly 1990;35:128-52.

[48] Lyles MA, Salk JE. Knowledge acquisition from foreign partners in international joint ventures. Journal of International Business Studies 1996;27(5):877-904.

[49] Lane PJ, Salk JE, Lyles MA. Absorptive capacity, learning, and performance in international joint ventures. Strategic Management Journal 2001;22:1139-61.

[50] Teece DJ, Pisano G, Shuen A. Dynamic capabilities and strategic management. Strategic Management Journal 1997;18(7):509-33.

[51] Kotabe M, Swan KS. The role of strategic alliances in hightechnology new product development. Strategic Management Journal 1995;16(8):621-36.

[52] Doz Y, Hamel G. Alliance advantage. Boston: Harvard Business School Press; 1998.

[53] Powell WW, Koput KW, Smith-Doerr L. Interorganizational collaboration and the locus of innovation: networks of learning in biotechnology. Administrative Science Quarterly 1996;41:116-45.

[54] Coleman JS. Social capital in the creation of human capital. The American Journal of Sociology 1988;94:95-120.

[55] McCardle KF. Information acquisition and the adoption of new technology. Management Science 1985;31(11):1372-89.

[56] Burt RS. Structure holes: the social structure of competition. Cambridge: Harvard University Press; 1992.

[57] Simonin B. The importance of collaborative know-how: an empirical test of the learning organization. Academy of Management Journal 1997;40(5):1150-74.

[58] Kranton R. The formation of cooperative relationships. Journal of Law, Economics and Organization 1996;12:214-33.

[59] Chan S, Kensinger J, Keown A, Martin J. Do strategic alliances create value?. Journal of Financial Economics 1997;46: 199-221.

[60] Huber GP. Organizational learning: the contributing processes and the literature. Organization Science 1991;2:88-115.

[61] Nelson RR, Winter SG. An evolutionary theory of economic change. Cambridge, MA: Belknap Press; 1982.

[62] Zollo M. Knowledge codification, process routinization and the creation of organizational capabilities. Doctoral dissertation, University of Pennsylvania, 1998.

[63] Kale P, Singh H. Alliance capability and success. Academy of Management Meetings, Chicago, IL, 1999.

[64] Pennings JM, Barkema H, Douma S. Organizational learning and diversification. Academy of Management Journal 1994;37:608-40.

[65] Baldwin TT, Danielson C, Wiggenhorn W. The evolution of learning strategies in organizations: from employee development to business redefinition. The Academy of Management Executive 1997;11(4):47-58.

[66] Cockburn I, Henderson R, Stern S. Untangling the origins of competitive advantage. Strategic Management Journal 2000;21(10-11):1123-45.

[67] Nonaka I. A dynamic theory of organization knowledge. Organization Science 1994;5:14-37.

[68] Grant RM, Baden-Fuller C. A knowledge-based theory of inter-firm collaboration. Academy of Management Journal 1995;Briarcliff Manor:17-21.

[69] Barney JB. Introduction to special issue on the resource based view of the firm. Journal of management 1991;17:97-9. 
[70] Pisano GP. Knowledge, integration, and the locus of learning: an empirical analysis of process development. Strategic Management Journal 1994;15(3):85-101.

[71] Benkard L. Learning and forgetting: the dynamics of aircraft production. The American Economic Review 1998;90: 1034-54.

[72] Chen H, Hu MY, Shieh JCP. The wealth effect of international joint ventures: the case of US investment in China. Financial Management 1991;20:31-41.

[73] Fama EF. Efficient capital markets: a review of theory and empirical work. Journal of Finance 1970;25:383-417.

[74] Brown SJ, Warner JB. Using daily stock returns: the case of event studies'. Journal of Financial Economics 1985;14(1): $3-31$.

[75] Lev B, Zarowin P. The boundaries of financial reporting and how to extend them. Journal of Accounting, Research 1999;37:353-85.

[76] Mouritsen J, Larsen HT, Bukh PND. Intellectual capital and the 'capital firm': narrating, visualizing and numbering for managing knowledge. Accounting, Organizations and Society 2001;26:735-62.

[77] Abeysekera I. Intellectual accounting scorecard-measuring and reporting intellectual capital. Journal of American Academy of Business 2003;3:422-7.

[78] Herremans IM, Isaac RG. The intellectual capital realization process (ICRP): an application of the resource-based view of the firm. Journal of Managerial Issues 2004;16(2):217-31.

[79] Barclay MJ, Smith CW. The maturity structure of corporate debt. Journal of Finance 1995;50(2):609-31.

[80] Chen SS, Ho KW. Market response to product-strategy and capital-expenditure announcements in Singapore: investment opportunities and free cash flow. Financial Management 1997;26:82-8.

[81] Holderness CG, Kroszner RS, Sheehan DP. Were the good old days that good? Changes in managerial stock ownership since the great depression. Journal of Finance 1999;54(2):435-69.

[82] Lindenberg E, Ross S. Tobin's $q$ ratio and industrial organization. Journal of Business 1981;54:1-32.

[83] Lang L, Stulz R, Walkling R. A test of the free cash flow hypothesis: the case of bidder returns. Journal of Financial Economics 1991;29:315-35.

[84] Chen SS, Ho KW, Lee CF, Yeo G. Investment opportunities, free cash flow and market reaction to international joint ventures. Journal of Banking and Finance 2000;24:1747-65.

[85] Lang L, Stulz R, Walkling R. Managerial performance, Tobin's $Q$ and the gains from successful tender offers. Journal of Financial Economics 1989;24(1):137-54.

[86] Das S, Sen P, Sengupta S. Impact of strategic alliances on firm valuation. Academy of Management Journal 1998;41:27-41.

[87] Lummer S, McConnell JJ. Stock valuation effects of international joint ventures. In: Rhee SG, Chang RP, editors. Pacific-basin capital markets research. New York; 1990. p. 531-46.

[88] Jensen MC. Agency cost of free cash flow, corporate finance, and takeovers. American Economic Review 1986;76(2):323-9.

[89] Szewezyk S, Tsetsekos G, Zantout Z. The valuation of corporate R\&D expenditures: evidence from investment opportunities and free cash flow. Financial Management 1996;25:105-10.

[90] Lee I, Wyatt S. The effects of international joint ventures on shareholder wealth. Financial Review 1990;25:641-9.

[91] Chen SS, Ho KW, IK KH, Lee CF. How does strategic competition affect firm values? A study of new product announcements. Financial Management 2002;31:67-84.
[92] Link AL, Long JE. The simple economics of basic science research. Journal of political economy 1981;67:297-306.

[93] Hambrick DG, MacMillan I. Efficiency of product R\&D in business units: the role of strategic context. Academy of Management Journal 1985;28:527-47.

[94] Chan S, Martin J, Kensinger J. Corporate research and development expenditures and share value. Journal of Financial Economics 1990;26(2):255-76.

[95] Kelm KM, Narayanan VK, Pinches GE. Shareholder value creation during $\mathrm{R} \& \mathrm{D}$ innovation and commercialization stages. Academy of Management Journal 1995;38(3):770-86.

[96] Smith R. Efficiency gains from strategic investments. Journal of Industrial Economics 1981;30:1-23.

[97] Lang L, Stulz R. Contagion and competitive intra-industry effects of bankruptcy announcements: an empirical analysis. Journal of Financial Economics 1992;32:45-61.

[98] Erwin GR, Miller JM. The intra-industry effects of open market share repurchases: contagion or competitive? Journal of Financial Research 1998;21(3):89-406.

[99] Amit R, Domowitz I, Fershtman C. Thinking one step ahead: the use of conjectures in competitor analysis. Strategic Management Journal 1988;9(5):431-42.

[100] Heil O, Robertson TS. Toward a theory of competitive market signaling: a research agenda. Strategic Management Journal 1991;12(6):403-18.

[101] Haunschild PR, Davis-Blake A, Fichman M. Managerial overcommitment in corporate acquisition process. Organization Science 1994;5:528-40.

[102] Zahra S, George G. Absorptive capacity: a review, reconceptualization, and extension. Academy of Management Review 2002;27(2):185-203.

[103] Gulati R. Does familiarity breed trust? The implications of repeated ties for contractual choices in alliances. Academy of Management Journal 1995;38:85-112.

[104] Boulton RE, Libert BD, Samek SM. A business model for the new economy. The Journal of Business Strategy 2000;21(4): 29-35.

[105] Liebowitz J, Suen CY. Developing knowledge management metrics for measuring intellectual capital. Journal of Intellectual Capital 2000;1(1):54.

[106] Kaplan RS, Norton DP. The balanced scorecard-measures that drive performance. Harvard Business Review 1992;70(1): 71-9.

[107] Contractor FJ, Lorange P. Evaluating strategic alliance performance. In: Cooperative strategies and alliances. 2002. p. $119-44$.

[108] Koh J, Venkatraman N. Joint venture formations and stock market reactions: an assessment in the information technology sector. Academy of Management Journal 1991;34:869-92.

[109] Namgyoo KP, John MM, Jaeyong S. A resource-based view of strategic alliances and firm value in the electronic marketplace. Journal of Management 2004;30(1):7.

[110] McWilliams A, Siegel D. Event studies in management research: theoretical and empirical issues. Academy of Management Journal 1997;40(3):626-57.

[111] Porter ME. From competitive advantage to corporate strategy. Harvard Business Review 1987;65(3):43-59.

[112] Ravenscraft DJ, Scherer FM. Mergers sell-offs and economic efficiency. Washington, DC: Brookings Institution; 1987.

[113] Healy PM, Palepu KG, Ruback RS. Does corporate performance improve after mergers. Journal of Financial Economics 1990;31(2):135-75. 
[114] Aiken LS, West SG. Mutiple regression testing and interpreting interactions. Newbury Park: Sage; 1991.

[115] Chung KH, Pruitt SW. Simple approximation of Tobin's q. Financial Management 1994;23:70-74.

[116] Singh K. The Impact of Technological Complexity and Interfrim Cooperation on Business Survival. Academy of Management Journal 1997;40(2):339-67.
[117] Baum JC, Oliver C. Institutional linkages and organizational morality. Administrative Science Quarterly 1991;36(2): $187-218$.

[118] Gomes-Casseres B. Group verses group: how alliance networks compete. Harvard Business Review 1994;72(4): $62-74$. 